\title{
Öğretmenevleri, Öğretmenevi ve Akşam Sanat Okulları Denetim Rehberinin Yasal Metinler ve Alanyazın Temelinde İncelenmesi
}

\author{
Dr.Öğr. Üyesi Hilal Kahraman \\ Sivas Cumhuriyet Üniversitesi-Türkiye \\ hyucel@cumhuriyet.edu.tr
}

\begin{abstract}
Özet:
Eğitim-öğretim faaliyetlerinin etkililiğinin değerlendirilmesinde gerçekleştirilen süreçlerden biri denetimdir. Denetimin temel amacı eğitim-öğretim amaçlarına ulaşılma derecesini saptamak ve daha iyi sonuçlar elde etmek için önlemler almaktır. Bu çalışmanın amacı, ögretmenevleri, ögretmenevi ve akşam sanat okulları denetim rehberinin yasal belgeler ve eğitim denetimi alanyazın temelinde incelenmesidir. Nitel araştırma yöntemlerinden doküman incelemesi yönteminin kullanıldı̆̆ çalışmada, veriler içerik analizine tabi tutulmuştur. Araştırmanın sonuçlarına göre, rehberin yasal belgelerle genel olarak tutarlı olduğu ancak bazı maddelerin yasal belgelere göre güncel olmadı̆̆ı yasal dayanak belirsizliğinin olduğu ve ilgili yasal dayanaklara eksik gönderme yapıldığı gibi noktalarda yasal belgelerle tutarsızlı̆ından söz edilebilir. Ayrıca rehberin alanyazınla da genel olarak tutarlı olduğu söylenebilirken; içerik eksikliği, atıfsızlık ve aykırlık kodlarıyla alanyazına göre tutarsızlığına değinilebilir.
\end{abstract}

Anahtar Kelimeler: Eğitim Denetimi, Denetim rehberi, Öğretmenevi, Akşam Sanat Okulları,

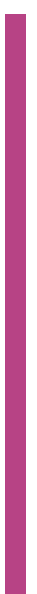

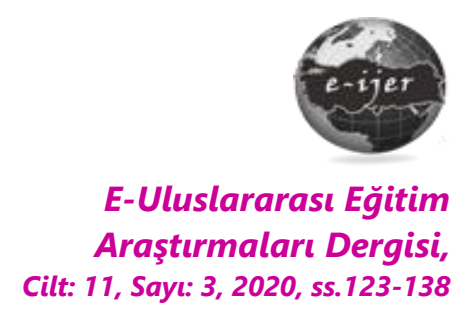

DOI: 10.19160/ijer.836759

\section{Önerilen Atıf}

Kahraman, H. (2020). Öğretmenevleri, Öğretmenevi ve Akşam Sanat Okulları Denetim Rehberinin Yasal Metinler ve Alanyazın Temelinde İncelenmesi, E-Uluslararası Eğitim Araştırmaları Dergisi, Cilt: 11, Sayı: 3, 2020, ss. 123-138, DOI: 10.19160/ijer.836759 


\section{Giriş}

Eğitim-öğretim faaliyetlerinin etkililiğinin değerlendirilmesinde gerçekleştirilen süreçlerden biri denetimdir. Eğitimde gelişme ve ilerlemenin sağlanması denetim aracılığıyla olmaktadır. Ayrıca eğitim kurumlarında yönetim sürecinin sağlıklı işlemesini sağlamak, sistemdeki aksaklıkları tespit etmek, kaynakların etkili kullanımını sağlamak, çalışanların uygulamalarının etkililiğini tespit etmek ve amaçlardan sapmayı önlemek gibi nedenlerle de denetime ihtiyaç duyulmaktadır (Başaran, 2008; Dündar, 2005). Aydın'a (2014) göre denetimin temel amacı eğitim-öğretim amaçlarına ulaşılma derecesini saptamak ve daha iyi sonuçlar elde etmek için önlemler almaktır. Bir başka deyişle eğitim denetimi okulların/kurumların girdi, süreç ve çıktılarının planlı ve programlı bir şekilde kontrol edilmesini sağlamaktadır (Memduhoğlu, 2012). Amaçlara ulaşılma derecesi hakkında bilgi sahibi olmanın amaçlandığı eğitim denetiminde, örgütsel işleyiş bir bütün olarak, planlı ve programlı bir biçimde sürekli olarak izlenir, eksik yönler saptanır, düzeltilir; hataların yenilenmesi engellenmeye ve daha sağlıklı bir işleyiş gerçekleştirilmeye çalışıır (Aydın, 2014: 1).

"Eğitimde denetim anlayışı, yönetime ilişkin yaklaşım ve kuramlara uygun bir değişim ve gelişim göstermiş̧ir. Yönetim kuramlarının ortaya koyduğu ilkelere, varsayımlara ve yaklaşımlara göre denetime bakış açıları da birbirinden farklılaşmıştır" (Aydın, 2008: 3). Günümüzde denetim sürecinin katııımcı, işbirlikçi, araştırma ve değerlendirmeye dayalı bir yaklaşımla ele alınması gerektiği vurgulanmaktadır (Balcı, Demirkasımoğlu, Erdoğan ve Akın, 2011). Bu süreçte denetmenin görevi ise işbirliği yapılmasını sağlamak ve liderlik etmektir (Sergiovanni ve Starratt, 2002).

Türkiye'de 20.08.2017 tarih ve 30160 sayılı MEB Teftiş Kurulu Yönetmeliği ile Milli Eğitim Bakanlığına bağıı birimlerde denetim süreçlerinin Maarif Müfettişleri aracılığı ile yürütüleceği açıklanmıştır. Bu doğrultuda Maarif Müfettişlerinin görevleri "rehberlik, denetim, inceleme, soruşturma, ön inceleme, araştırma, izleme-değerlendirme ve diğer görevler" (Teftiş Kurulu Başkanlığı, 2019) şeklinde ifade edilmiştir. Denetim süreçlerine yön veren ilkelerin belirlenmesi ve denetim süreçlerine rehberlik edilmesine yönelik olarak Milli Eğitim Bakanlığı Teftiş Kurulu Başkanlığı tarafından "Denetim Rehberleri" hazırlanmıştır. Denetim rehberlerinin amacı; Bakanlığın görev alanına giren konularda Bakanlık personeline, Bakanlık okul ve kurumlarına, özel öğretim kurumlarına, gerçek ve tüzel kişilere rehberlik etmek; sunulan hizmetlerin kontrol ve denetimini ilgili birimlerle iş birliği içinde yapmak, süreç ve sonuçlarını mevzuata, önceden belirlenmiş amaç ve hedeflere, performans ölçütlerine ve kalite standartlarına göre analiz etmek, karşılaştırmak ve ölçmek, kanıtlara dayalı olarak değerlendirmek, elde edilen sonuçları rapor hâline getirerek ilgili birimlere ve kişilere iletmek; Maarif Müfettişleri Başkanlıkları arasında uygulama birliği ve standartlaşmayı sağlamaktır. Denetim rehberleri değişen ve gelişen şartlara göre sorunları belirlemek, çözümünü ortaya koyabilmek, mevcudu iyileştirmek ve performansı yükselterek kaliteyi artırmak, kamu kaynaklarını daha etkin, verimli ve yerinde kullanmak amacıyla Bakanlığa bağlı okul, kurum ve birimlerin özellikleri dikkate alınarak oluşturulmuştur (MEB, 2016). Bu denetim rehberlerinden birisi de "Öğretmenevleri, Öğretmenevi ve Akşam Sanat Okulları Rehberlik ve Denetim Rehberi"dir. Bu çalışma boyunca "denetim rehberi" olarak anılacaktır.

Öğretmenevi, öğretmenevi ve akşam sanat okulunun asıl amacı eğitim çalışanlarının konaklama intiyacını karşılamaktır. Bununla birlikte dinlenme ve eğlenme ihtiyaçlarını da imkânları ölçüsünde yerine getirmektedir. Kurum, eğitim çalışanlarının sosyal ve kültürel ihtiyaçları ile meslekî eğitim alanında gelişimlerine ilişkin faaliyetlere imkânları ölçüsünde destek vermektedir. Ayrıca işletmelerde meslek eğitimi uygulaması kapsamında meslekî ve teknik eğitim okul ve kurum öğrencilerinin stajyerlik ve çıraklık beceri eğitimi yapmalarına katkı sağlamaktadır (MEB, 2013). Milli Eğitim Bakanlığı Teftiş Kurulu Başkanlığı tarafından yayınlanan Denetim Rehberi'nde (2016) öğretmenevi, öğretmenevi ve akşam sanat okullarında denetim sürecinin Maarif 
Müfettişleri aracılığı ile söz konusu rehberden yararlanılarak yapılacağı belirtilmektedir. Bu nedenle rehberin hem denetlenen kuruma hem de denetleyenlere yol gösterici nitelikte olması için mümkün olduğunca hatalardan arınmış olması gerekmektedir. Bu anlamda denetim rehberinin yasal metinler ve bilimsel bilgiler temelinde araştırılması önemli görünmektedir. Bir denetim rehberi elbette yasalara dayanmalıdır. Bunun yanında aynı denetim rehberinin bilimsel bilgiler ışığında şekillenmesi gerektiği de ortadadır.

Eğitimde denetim konusunda yapılan çalışmalar incelendiğinde genellikle okul müdürlerinin denetim sürecindeki rolleri (Topçu, 2010; Öz, 2003) ve öğretmen denetimi (Aslanargun ve Göksoy, 2013; Aslanargun ve Tarku, 2014) gibi konulara odaklanıldığı ve örgün eğitim kurumlarındaki denetim süreçlerinin incelendiği görülmektedir. Ancak öğretmenevleri ve akşam sanat okullarının denetlenmesine yönelik araştırmalar oldukça sınılıdır. Bu çalışmalar da öğretmenevleri ve akşam sanat okullarının denetlenmesine yönelik değil, öğretmenlerin öğretmenevleri üzerine görüşlerinin araştıııldığı (Vatanartıran ve Güvenç, 2014) ve öğretmenevlerinin gerekliliğini sorgulayan (Sağlam, 2014) çalışmalardır. Bu çalışmanın amacı Öğretmenevleri ve Akşam Sanat Okullarının Denetim Rehberinin yasal belgeler ve alanyazın temelinde incelenmesi ve araştırma sonuçları kapsamında uygulayıcılara ve araştırmacılara öneriler geliştirilmesidir.

\section{YÖNTEM}

\section{Araştırmanın Modeli}

Öğretmenevleri, Öğretmenevi ve Akşam Sanat Okulları Denetim Rehberinin yasal belgeler ve eğitim denetimi alanyazını temelinde değerlendirilmesinin amaçlandığı bu çalışmada, bir durumun ya da olayın derinlemesine ve ayrıntılı bir biçimde çalışılmasının amaçlandığı nitel araştırmalar (Bogdan ve Biklen, 1998: 5) kapsamında doküman incelemesi yöntemi kullanılmıştır. Basılı ve elektronik belgelerin incelenmesi veya değerlendirilmesini içeren sistematik bir işlem (Bowen, 2009) olarak da tanımlanabilecek doküman incelemesinde amaç, araştırılması hedeflenen olgu veya olgular hakkında bilgileri içeren yazılı ve görsel materyallerin analiz edilmesidir (Yıldııım ve Şimşek, 2008: 187). Bu amaçla bir kamu dokümanı olan, MEB Teftiş Kurulu Başkanlığı tarafından denetimde uygulama birliği ve standartlaşmayı sağlamak amacıyla hazırlanan denetim rehberleri, etkili birer veri kaynağı olarak doküman analizine tabi tutulmuştur.

\section{Çalışma Dokümanı, Verilerin Toplanması ve Analizi}

MEB Teftiş Kurulu Başkanlığı tarafından 2016 yılında çeşitli kurumların teftişine yönelik olarak hazırlanan, maarif müfettişlerinin teftiş sürecinde uygulayacakları esasları içeren 16 adet denetim rehberinden "Öğretmenevleri, Öğretmenevi ve Akşam Sanat Okulları Denetim Rehberi" bu çalışmanın temel dokümanını oluşturmaktadır. Bu doküman çalışma boyunca "denetim rehberi" ya da "rehber" olarak ifade edilecektir. Söz konusu dokümana MEB Teftiş Kurulu Başkanlığı'nın resmi internet sitesinin "Yayınlar" sekmesinden 23.04.2020 tarihinde ulaşılmıştır. Ayrıca çalışmada kullanılan yasal belgelere (kanun, KHK, tüzük, yönetmelik, yönerge, genelge ve diğer belgeler) bakanlığın kendi sitesinden ulaşılmış ve orijinalliği teyit edilmiştir. Son olarak rehberin alanyazınla tutarlılığının incelenmesinde kullanılan dokümanları ise çevrim içi ortam ile araştırmacının gerçek ve sanal kütüphanesinde bulunan kaynaklar oluşturmaktadır. Bu yönüyle yapılan inceleme belirtilen kaynaklar sınırlılı̆ında gerçekleştirilmiştir. 
Tablo 1. Öğretmenevleri, ögretmenevi ve akşam sanat okulları denetim rehberinin yasal belgeler ve alanyazın temelindeki analizi sonucu kod, kategori ve temalara ilişkin örnek ifadeler

\begin{tabular}{|c|c|c|c|}
\hline Temalar & Kategoriler & Kodlar & IFADELER \\
\hline \multirow{4}{*}{$\begin{array}{c}\text { Denetim } \\
\text { Rehberinin } \\
\text { Yasal } \\
\text { Belgelerle } \\
\text { İlişkisi }\end{array}$} & \multirow[t]{2}{*}{$\begin{array}{c}\text { Denetim } \\
\text { Rehberinin } \\
\text { Yasal } \\
\text { Belgelerle } \\
\text { Tutarlılığı }\end{array}$} & $\begin{array}{c}\text { Yasal } \\
\text { belgeye } \\
\text { uygunluk }\end{array}$ & $\begin{array}{l}\text { Rehberde; } \\
\text { Kurum yönetimince hizmetin niteliğine göre tespit edilen kuralların gerekli } \\
\text { tanıtıcl-bilgilendirici materyaller ile kurum hizmetlerinden yararlananlara } \\
\text { duyurulması (Millı̈ Eğitim Bakanlığı Ögretmenevi, Ögretmenevi ve Akşam } \\
\text { Sanat Okulu Uygulama Yönergesi Md.15)şeklinde olan maddenin, } \\
\text { Yasal Belgedeki Karşı̆ığı; } \\
\text { MADDE 15- (1) "Yönetimce hizmetin niteliğine göre tespit edilen kurallar, } \\
\text { gerekli tanıtıcı -bilgilendirici materyaller ile kurum hizmetlerinden } \\
\text { yararlananlara duyurulur"şeklindedir. }\end{array}$ \\
\hline & & $\begin{array}{l}\text { Rehberde belirtil } \\
\text { "yasal belgeye uy }\end{array}$ & $\begin{array}{l}\text { naddenin, gönderme yapılan yasal belgedeki ifadeyle örtüşmesinden dolayı } \\
\text { unluk kodu" tercih edilmiştir. }\end{array}$ \\
\hline & \multirow[t]{2}{*}{$\begin{array}{c}\text { Denetim } \\
\text { Rehberinin } \\
\text { Yasal } \\
\text { Belgelerle } \\
\text { Tutarsızlığı }\end{array}$} & $\begin{array}{c}\text { İlgili yasal } \\
\text { dayanaklara } \\
\text { eksik } \\
\text { gönderme }\end{array}$ & $\begin{array}{l}\text { Rehberde; } \\
\text { "Kurum bina ve tesislerinin güvenliğinin Milli Eğitim Bakanlığı Koruyucu } \\
\text { Güvenlik Özel Talimatı Hükümlerine uygun olma durumu" şeklinde olan } \\
\text { maddede, } \\
\text { Yasal Belgedeki Karşılığı; } \\
\text { "26.04.2018 tarih ve 24301423-918.99-E.8310247 Sayılı Okullarda Güvenlik } \\
\text { Önlemlerinin Alınması Konulu 2018/10 Nolu Genelge" ye atıf yapılmamıştır. }\end{array}$ \\
\hline & & \multicolumn{2}{|c|}{$\begin{array}{l}\text { Rehberde belirtilen maddede, yukarıda belirtilen yasal dayanağa da gönderme yapılmamasından } \\
\text { kaynaklı "ilgili yasal dayanaklara eksik gönderme kodu" tercih edilmiştir. }\end{array}$} \\
\hline \multirow{4}{*}{$\begin{array}{l}\text { Denetim } \\
\text { Rehberinin } \\
\text { Alanyazınla } \\
\text { İlişkisi }\end{array}$} & $\begin{array}{l}\text { Denetim } \\
\text { Rehberinin } \\
\text { Alanyazınla } \\
\text { Tutarlıı̆ı̆ı }\end{array}$ & Uygunluk & $\begin{array}{l}\text { Rehberde; } \\
\text { "Denetim, (...) yapılmakta olan işlerin; (...) yasal çerçeve ile belirlenen amaç, } \\
\text { öngörülen temel ilke ve hedeflere uygunluğunu, doğruluğunu, düzenliliğini, } \\
\text { verimliliğini, ekonomikliğini, etkinliğini; objektif, geçerli, güvenilir ölçütlere } \\
\text { göre karşılaştırma yapabilme (...) sürecidir." şeklinde olan maddenin, } \\
\text { Alanyazındaki Karşılı̆ı̆; } \\
\text { "Genel olarak denetim, yapılan işlerin (...) verimlilik etkinlik ve ekonomik } \\
\text { derecelerini ölçmek, karşılaştırmak ve değerlendirmek işidir. Bu yönüyle } \\
\text { denetim standartlara uygunluk araştırmasıdır (Arslan, 2002)." şeklindedir. }\end{array}$ \\
\hline & & \multicolumn{2}{|c|}{$\begin{array}{l}\text { Rehberde belirtilen maddenin, alanyazındaki ifadeyle örtüşsmesinden dolayı "uygunluk kodu" } \\
\text { tercih edilmiştir. }\end{array}$} \\
\hline & $\begin{array}{c}\text { Denetim } \\
\text { Rehberinin } \\
\text { Alanyazınla } \\
\text { Tutarsızlığı }\end{array}$ & $\begin{array}{c}\text { İçerik } \\
\text { eksikliği }\end{array}$ & $\begin{array}{l}\text { Rehberde; } \\
\text { "Tanımlar" bölümünde 'Denetim, Rehberlik, Denetim Bilgi İşlem Sistemi, } \\
\text { Denetim Emri, Grup Sorumlusu, Denetim Öncesi Hazırlık Toplantısı, Çalışma } \\
\text { Planı, Bilgi Notu (Föy), Değerlendirme Toplantısı, Rapor, Raportör ve Geliş̧m } \\
\text { Planı" kavramlarının tanımlarına yer verilmiştir. } \\
\text { Alanyazındaki Karşılığı; } \\
\text { Eğitim sisteminde denetim, ders denetimi ve kurum denetimi olmak üzere } \\
\text { ikiye ayrılır. Ders denetimi; öğretmenlerin yetkinliği, çalışmaları, uyguladığı } \\
\text { yöntemleri, bunları uygulamadaki yeterliliklerini ve öğrencilerin yetişme } \\
\text { düzeylerini inceleyip, değerlendirmektir. Kurum denetimi ise bir eğitim } \\
\text { kurumunda, kurum çalışmalarını güçlendiren veya zayıflatan nedenlerin } \\
\text { saptanarak gerekli önlemlerin yerinde ve zamanında alınması, insangücü ve } \\
\text { madde kaynağının verimli bir biçimde kullanımasının sağlanması amacıyla } \\
\text { durumun gözlenmesi, kontrol edilmesi ve belli kriterlere göre } \\
\text { değerlendirilmesidir (Taymaz, 2002)" şeklindedir. }\end{array}$ \\
\hline & & \multicolumn{2}{|c|}{$\begin{array}{l}\text { Rehberde belirtilen maddenin, alanyazındaki ilave bilgisinden dolayı "içerik eksikliği kodu" tercih } \\
\text { edilmiştir. }\end{array}$} \\
\hline
\end{tabular}

Çalışma verilerinin analizinde içerik analizi tekniği kullanılmıştır. İçerik analizinde toplanan verilerin açıklanmasına yardımcı olacak kavramalara ulaşmak amaçlanarak, birbirine benzeyen veriler belirli kavramlar ve temalar çerçevesinde bir araya getirilerek okuyucunun anlayabileceği bir biçimde düzenlenerek yorumlanır. Nitel araştırmalar, verilerin kodlanması, temaların bulunması, kodların ve temaların düzenlenmesi ile bulguların tanımlanması olmak üzere dört aşamada analiz edilir (Yıldııım ve Şimşek, 2008: 227-228). Çalışma bu aşamalara uygun olarak iki bölümde tasarlanmıştır. İlk bölümde rehberin yasal belgelerle tutarlılığı incelenirken, öncelikli olarak rehber ve gönderme yaptığı yasal belgeler incelenmiş, kod, kategori ve temalar belirlenmiş ve rehberdeki karşılıkları sayısallaştıılarak ifade edilmiştir. Rehberin alanyazınla tutarlılığı çerçevesinde ise rehber araştırmacı tarafından, araştırmacının zihinsel çerçevesi temelinde tekrar tekrar okunmuş ve bu okumalar sırasında kod, kategori ve temalar belirlenmiştir. Rehberin alanyazınla tutarlılığının incelenmesinde, kod, kategori ve temaların 
rehberdeki karşılıkları, öğretmenevleri ve akşam sanat okulları ile denetim rehberlerine dair çalışmaların sınırlıı̆ına binaen, denetim ile ilgili dolaylı çalışmalar çerçevesinde yapıldığından sayısallaştırma yoluna gidilmemiştir. Rehberin hem yasal belgelerle hem de alanyazın ile tutarlıı̆̆ının analizi sürecinde çelişkiye düşülen durumlarda kaynaklara, meslektaş teyidine ve uzman görüşüne başvurulmuştur. Süreç ayrıntılı olarak ifade edilmek istenirse; denetim rehberinin yasa ve alanyazın ile olan ilişkisi temalar olarak biçimlenirken, yasal belgeler ve alanyazın ile ilişkisinde tutarlılık ve tutarsızlık kategoriler olarak biçimlenmiş ve son olarak ayrı ayrı olmak üzere onların altında da "Yasal dayanağa uygunluk", "Yasal dayanağa göre güncel olmama", "Yasal dayanak belirsizliği", "ilgili yasal dayanaklara eksik gönderme", "Yasal boşluk", "Yasal dayanağa internet ortamında ulaşamama", "Yasal dayanağa göre eksik ifade edilme", "Yasal dayanağın hatalı ifade edilmesi", "Yasal dayanağa göre fazla ifade edilme", "Uygunluk", "içerik eksikliği", "Atıfsızlık" ve "Aykırılık" ise kodlar olarak biçimlenmiştir. Tablo 1 de bahsedilen süreç örneklendirilerek anlatılmıştır.

\section{Geçerlik ve Güvenirlik:}

Araştırmanın geçerlik ve güvenirliğinin sağlanmasında "çoklu analizci üçgenlemesi" (Patton, 2014) ve "uzman incelemesi" (Merriam, 2013) yöntemlerine başvurulmuştur. Çoklu analizci üçgenlemesi, tekil analizci yerine, çoklu analizci kullanılmasıyla elde edilen üçgenlemedir. Burada amaç, tüm analiz sürecinin tek bir kişi tarafından yapılmasından kaynaklanan olası ön yargıları azaltmaya yardımcı olması ve verilerin iki veya daha fazla kişiyle analiz edilerek bulguların karşılaştıııması yoluyla tutarılı̆̆ın sağlanmasıdır (Patton, 2014: 560). Uzman incelemesi ise, araştırmanın ham verilerinin, çalışmanın konusu ve metodolojisi hakkında uzman olan kişiler tarafından gözden geçirilmesi ve ortaya konulan bulguların makul ve mantıklı olup olmadıklarının denetlenmesidir (Merriam, 2013: 210). Araştırmanın geçerlik ve güvenirliğinin sağlanmasında ilk olarak çoklu analizci üçgenlemesi yöntemi kullanılmıştır. Bu amaçla MEB Teftiş Kurulu Başkanlığı'nın farklı kurumlara yönelik denetim rehberlerini inceleyen araştırmacılar düzenli aralıklarla her hafta belirlenen gün ve saatte internet ortamında canlı toplantı araçları üzerinden bir araya gelmiş ve toplantılar tekrar izlenebilmesi için kaydedilmiştir. Toplantılarda ilk olarak rehberlerin hangi yönlerden incelenebileceğini ilişkin tartışmalar yapılmıştır. Sonrasında ise araştırmacılar inceledikleri rehberlere yönelik içerik analizi yaparak kod, kategori ve temaları oluşturmuş ve bunların benzer ve farklı yönleri üzerinde durmuştur. Anlaşmazlığa düşülen noktalar değerlendirilmiş ve fikir birliğine varıncaya kadar toplantılar devam etmiştir. Ayrıca geçerlik ve güvenirliğin sağlanması için değerlendirilen rehberlerin ayrıntılı raporlaştııılmasına dikkat edilmiştir. Rehberdeki alıntıların değiştirilme yapılmadan doğrudan verilmiş olması, araştırmanın güvenirliğini göstermektedir. Tüm bunların dışında uzman incelemesi için denetim alanında yetkin ve yayınları olan bir akademisyen ile bir maarif müfettişi bu toplantıda yer alarak toplantı süresince geri bildirimlerde bulunmuşlardır. Son toplantının ardından çalışma alanında uzman akademisyenlere gönderilmiş ve onların görüşleri de çalışmaya dâhil edilmiştir.

\section{BULGULAR VE YORUM}

Araştırmanın bulguları, "Öğretmenevleri, Öğretmenevi ve Akşam Sanat Okulları Denetim Rehberinin Yasal Belgelere Uygunluğu" ve "Öğretmenevleri, Öğretmenevi ve Akşam Sanat Okulları Denetim Rehberinin Alanyazına Uygunluğu" başlıklarında sunulmuştur.

\section{1. Öğretmenevleri, Öğretmenevi ve Akşam Sanat Okulları Denetim Rehberinin Yasal Belgelere Uygunluğu:}

denetim rehberinin yasal belgelere uygunluğunun değerlendirilmesi amacıyla, rehberde atıf yapılan/yapılması gereken yasal belgeler incelenmiş; denetim rehberindeki maddelerin yasal 
belgelerle kıyaslandığında doğruluğu, güncelliği, ulaşılabilirliği, eksikliği, fazlalığı gibi sorulara yanıt aranmıştır. Tablo 2'de denetim rehberinin yasal belgelere uygunluğunun değerlendirilmesi sonucunda ulaşılan tema, kategori ve kodlar frekansları ile belirtilmiştir.

Tablo 2. Öğretmenevleri, Öğretmenevi ve Akşam Sanat Okulları Denetim Rehberinin Yasal Belgelere Uygunluğu

\begin{tabular}{|c|c|c|c|}
\hline Tema & Kategoriler & Kodlar & Frekans \\
\hline \multirow{10}{*}{ 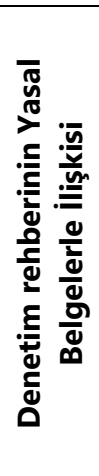 } & $\begin{array}{l}\text { Denetim Rehberinin Yasal } \\
\text { Belgelerle Tutarlılığı }\end{array}$ & Yasal dayanağa uygunluk & 108 \\
\hline & \multirow{9}{*}{$\begin{array}{l}\text { Denetim Rehberinin Yasal } \\
\text { Belgelerle Tutarsızlığı }\end{array}$} & Yasal dayanağa göre güncel olmama & 31 \\
\hline & & Yasal dayanak belirsizliği & 28 \\
\hline & & İlgili yasal dayanaklara eksik gönderme & 19 \\
\hline & & Yasal boşluk & 6 \\
\hline & & Yasal dayanağa internet ortamında ulaşamama & 5 \\
\hline & & Yasal dayanağa göre eksik ifade edilme & 5 \\
\hline & & Yasal dayanağın hatalı ifade edilmesi & 2 \\
\hline & & Yasal dayanağa göre fazla ifade edilme & 1 \\
\hline & & Toplam & 97 \\
\hline
\end{tabular}

Tablo 2 incelendiğinde denetim rehberinin yasal belgelerle genel olarak tutarlı $(f=108)$ olduğu söylenebilir. Bununla birlikte öğretmenevleri ve akşam sanat okullarının denetiminde uygulanacak esasları belirlemek için oluşturulan denetim rehberindeki birçok maddenin de $(f=97)$ yasal belgelerle tutarsızlığından söz edilebilir.

Bulgular genel olarak değerlendirildiğinde; denetim rehberinin, denetime referans oluşturan yasal belgelerle tutarlı olması beklenen bir bulgudur. Ancak rehberin yasal belgelerle tutarsızlığını vurgulayan, rehberde atıfta bulunulan yasal dayanağın hatalı ifade edilmesi, belirsizliği, güncel olmaması, eksik, hatalı ya da fazla ifadelendirilmesi gibi kodlar da rehberde karşılaşılan ve olumsuz olarak değerlendirilebilecek bulgular olarak karşımıza çıkmaktadır. Denetim rehberinin, rehberde ifade edildiği biçimiyle maarif müfettişlerine denetimlerde yol göstermek, kurum denetiminde uygulama birliği sağlamak ve sorunlu alanların önceliklendirilerek denetim yapılmasını gerçekleştirmeyi amaçladığı düşünüldüğünde; denetimlerde referans kaynağı olan yasal belgelerle tutarlı olması beklenirdi.

Denetim rehberinde, "Denetimlerde yürürlükteki hukuki düzenlemeler dikkate alınacaktır. Ayrıca denetim rehberinde yer almayan hususlar için ilgili mevzuat hükümlerine göre rehberlik ve denetim yapılacaktır. Rehberde yer alan mevzuat atıfları bilgi amaçlıdır (MEB, 2016)" ifadesi her ne kadar sınırlılık olarak belirtilse de; bu rehberin yenisi hazırlanana kadar denetimlerde kullanılmaya devam edecek olması, rehberin güncel yasal dayanaklar çerçevesinde revize edilmesini gerekli kılar. Dijitalleşmenin yaygın olduğu günümüz koşullarında, denetim rehberinin belirli aralıklarla güncellenmesi ve yeni yasal dayanaklar çerçevesinde revize edilmesi zorunlu görünmektedir.

Çalışmanın kategorileri ayrı ayrı değerlendirildiğinde; denetim rehberinin atıf yapılan yasal dayanaklarla tutarlıı̆ını ifade eden "yasal dayanağa uygunluk" kodunda 108 maddenin bulunduğu görülmektedir. Bu maarif müfettişleri başkanlıkları arasında uygulama birliği ve standartlaşmayı sağlamak amacıyla hazırlanan denetim rehberinde bulunması gereken bir özelliktir. Örnek vermek gerekirse; maarif müfettişlerinin görevleri denetim rehberinde aşağıdaki haliyle geçmektedir;

"a) 652 sayılı Kanun Hükmünde Kararnamenin 17'nci maddesinde belirtilen görevleri yapmak,

b) Rehberlik, denetim, inceleme, soruşturma çalışmaları neticesinde düzenleyecekleri raporları en geç yirmi gün, kapsamlı işlerde ise verilen ek süre içinde tamamlamak (...)" 
Burada atıfta bulunulan 652 sayılı Millî Eğitim Bakanlığının Teşkilat ve Görevleri Hakkında Kanun Hükmünde Kararname'nin 17. Maddesi de "Rehberlik ve Denetim Başkanlığının Görevlerini" belirtmekte yani denetim rehberinde ifade edilen maddeyle uygun görünmektedir. Bu koda ilişkin maddelerin fazlalığı, başka bir deyişle rehberin yasal belgelerle tutarlı oluşu beklenen ve ayrıca rehberin niteliği ile ilgili olarak olumlu olarak değerlendirilebilecek bir bulgudur.

Bunun yanında denetim rehberinin yasal belgelerle tutarsızlığını ifade eden kodlardan biri olarak karşımıza çıkan, rehberdeki ifadenin ya da bu ifadenin yanında yer alan yasal belgenin güncel olmadığı ya da yürürlükten kaldırıldığı durumlarda tercih edilen "yasal dayanağa göre güncel olmama" kodu, metin içerisinde 31 kez tekrarlanmıştır. Örneğin, denetim rehberinin kapsam ve sınırlılığında aşağıdaki ifade vurgulanmıştır.

"Bu denetim rehberi hazırlanırken, Millî Eğitim Bakanlığı Rehberlik ve Denetim Başkanlığı ile Maarif Müfettişleri Başkanlıkları Yönetmeliğinde belirtilen denetim hizmetlerinin çeşitleri referans alınmıştır."

Bu ifadede atıfta bulunulan "Millî Eğitim Bakanlığı Rehberlik ve Denetim Başkanlığı ile Maarif Müfettişleri Başkanlıkları Yönetmeliği", 24.5.2014 tarih ve 29009 sayılı Resmî Gazetede yürürlükten kaldırımış, yerine 2017 yılında "Milî Eğitim Bakanlığı Teftiş Kurulu Yönetmeliği" yayınlanmıştır. Bu bulgunun, öğretmenevleri ve akşam sanat okullarının denetimini gerçekleştirecek olan müfettişlere yol gösterici olması amacıyla hazırlanan denetim rehberinde bulunması şaşırtıcıdır. Her ne kadar atıfta bulunulan yasal dayanaklar denetim rehberinin hazırlandığı tarihte yürürlükte olsa da, araştırmanın bu bulgusu günümüzde ilgili kurumların denetiminde halen kullanılan denetim rehberinin güncellenmesi gerekliliğini ortaya koymaktadır.

Denetim rehberinin yasal belgelerle tutarsızlığını ifade eden bir diğer kod "yasal dayanak belirsizliği" kodudur $(f=28)$. Yasal dayanak belirsizliği kodu, rehberde ilgili konuya ilişkin yasal belgeye açıkça gönderme yapılmadığı durumlar tespit edildiğinde kullanılmıştır. Bu koda denetim rehberinin "yiyecek-içecek üniteleri" başlığındaki şu ifade örnek gösterilebilir.

"Üretimde kullanılan gereçlerin gıda güvenliği açısından değerlendirilmesi (Gıda güvenliği,

hijyen, saklama koşulları, Ürünlerin Son Kullanım Tarihleri, Standartlara uygunluğu TSE)"

Görüldüğü gibi yukarıdaki maddede konuya ilişkin hiçbir yasal belgeye atıf yapılmamıştır. Oysa10.11.2020 tarih ve 16476274 sayılı Resmi Gazete'de yayınlanan 2020/8 nolu "Okul Kantinlerinde Satılacak Gıdalar ve Eğitim Kurumlarındaki İşletmelerinin Hijyen Yönünden Denetlenmesi" genelgesi ile 22.10.2020 tarih ve 31282 sayılı Resmi Gazetede yayınlanan 2020/23 sayılı "Okul Gıdası Hakkında Tebliğ" burada bahsedilen konuyla ilişkili olarak atıf yapılması gereken yasal metinlerdir. Bu belgelere atıf yapılmaması rehberin yayınlandığı tarihte bu yasal belgelerin yürürlükte olmamasıyla açıklanabilir ancak çalışma boyunca vurguladığımız, rehberin değişen yasal belgeler ışığında güncellenmesi gerekliliği burada da karşımıza çıkmaktadır.

Yasal belgelerle tutarsızlığı ifade eden bir diğer kod da "ilgili yasal dayanaklara eksik gönderme" kodudur ( $f=19$ ). Bu kod, rehberdeki ilgili maddede atıf yapılan belgede başka maddelere de atıf yapılması gerekiyorsa ya da gönderme yapılan yasal belge dışında rehberde değinilmeyen başka destekleyici belgeler de varsa tercih edilmiştir. Örneğin, rehberin "Kurumun Kuruluş İşlemleri ve Genel Durumu" başlığında aşağıdaki ifade yer almaktadır.

"Kurum açıışında mevzuatta belirtilen usul ve esaslara uyulma durumu (Millî Eğitim

Bakanlığı Öğretmenevi, Öğretmenevi ve Akşam Sanat Okulu Uygulama Yönergesi Md.10)"

Yapılan araştırmalar sonucunda yukarıdaki maddede atıf yapılan yasal belge dışında 30106 sayılı Resmî Gazete'de yayınlanan ve 31262 sayılı Resmî Gazete'de değişikliklerle güncellenen "Millî Eğitim Bakanlığı Kurum Açma, Kapatma ve Ad Verme Yönetmeliği'nin" bir sosyal tesisin açılabilmesi için gerekli olan koşulların belirtildiği 11. Maddesi burada atıf yapılması gereken diğer bir yasal metindir. Benzer şekilde rehberin "Sivil Savunma Önlemleri" başlığında, 
"Kurum bina ve tesislerinin güvenliğinin Milli Eğitim Bakanlığı Koruyucu Güvenlik Özel

Talimatı Hükümlerine uygun olma durumu"

şeklinde belirtilen maddede 26.04.2018 tarih ve 8310247 sayılı Resmi Gazetede yayınlanan 2018/10 sayılı "Okullarda Güvenlik Önlemlerinin Alınması Konulu Genelge"ye ve "22.12.2016 tarihli "Okullarda Güvenli Ortamın Sağlanmasına Yönelik Koruyucu ve Önleyici Tedbirlerin Arttırılmasına Illişkin İşbirliği Protokolü"ne gönderme yapılmadığından bu kod kapsamında değerlendirilmiştir. "ilgili yasal dayanaklara eksik gönderme" kodu, rehber içerisinde 19 kez tekrarlanmıştır. Bu bulgu, rehberin hazırlanma sürecinde her yasal belgeye ve her maddeye yer vererek fazla detaya girmek istenmemesi şeklinde yorumlanabilir. Ancak bu rehberin deneticiye yol gösterici olduğu düşünüldüğünde, rehberde eksik olan maddelere ve yasal dayanaklara da yer verilmesinin denetimin niteliği açısından önemli olduğu söylenebilir.

"Yasal boşluk" kodu $(f=6)$, denetim rehberinin yasal belgelerle tutarsızlığı kategorisinde değerlendirilen bir diğer koddur. Rehberde yer alan içeriğe ilişkin hiçbir yasal belgenin olmadığı durumlarda tercih edilen "yasal boşluk" kodu, rehber içerisinde 6 kez tekrarlanmıştır. Örnek vermek gerekirse; rehberin "Personel işsleri" bölümünde, "Personel nöbet hizmetlerinin düzenlenmesi" ile ilgili olarak hiçbir yasal belgeye ulaşılamamıştır. Bu bulgu, eğitim kurumlarında bazı faaliyetlerin yürütülmesinde yasal belgelere intiyaç duyulmamasından kaynaklanabilir.

Denetim rehberinin yasal belgelerle tutarsızlığı kategorisinde yer alan diğer bir kod ise "Yasal dayanağa internet ortamında ulaşamama" $(f=5)$ kodudur. Bu koda rehber içerisindeki atıf yapılan yasal dayanağa internet ortamında ulaşılamadıysa başvurulmuştur. Metinde 5 kere tekrarlanan bu bulgu, rehberde atıf yapılan yasal belgelerin yürürlükten kaldırılığı ya da bu belgenin internet ortamına yüklenmediği şeklinde yorumlanabilir. Örneğin, rehberde "Sivil Savunma Önlemleri" başlığının "Kurum bina ve tesislerinin güvenliğinin Milli Eğitim Bakanlığı Koruyucu Güvenlik Özel Talimatı Hükümlerine uygun olma durumu" maddesi örnek gösterilebilir. Burada atıf yapılan "Milli Eğitim Bakanlığı Koruyucu Güvenlik Özel Talimatı"na internet ortamında ulaşılamamıştır. Bu bulgular, daha öncede değinildiği gibi denetimin sağlıklı bir şekilde gerçekleşebilmesi için deneticiye yol gösterici olan denetim rehberinin güncellenmesi gerekliliğini bir kere daha ortaya çıkarmaktadır.

"Yasal dayanağa göre eksik ifade edilme" $(f=5)$ kodu, denetim rehberinin yasal belgelerle tutarsızlığı kategorisinde yer alan bir diğer koddur. Bu koda rehberde yer alan metin, atıf yapılan yasal belgeye göre eksik ifade edildiğinde başvurulmuştur. Metin içerisinde toplam 5 kere tekrarlanan "yasal dayanağa göre eksik ifade edilme" koduna, "Amaç, Kapsam, Dayanak ve Tanımlar" başlığının, "Tanımlar" alt başlığı örnek gösterilebilir. Burada "Denetim, Rehberlik, Rehberlik ve Denetim Bilgi İşlem Sistemi, Denetim Emri, Grup Sorumlusu, Rehberlik ve Denetim Öncesi Hazırlık Toplantısı, Çalışma Planı, Bilgi Notu (Föy), Değerlendirme Toplantısı, Rapor, Raportör, Gelişim Planı" gibi kavramların tanımlarına yer verilmiştir. Ancak incelenen rehber düşünüldüğünde, "öğretmenevleri, öğretmenevi ve akşam sanat okulu", "kurum", "kurum personeli", "eğitim çalışanı" gibi kavramların da yer alması beklenirdi. Bu kavramlar, Şubat 2013 tarih ve 2665 tarihli Tebliğler Dergisi'nde yayınlanan "Millî Eğitim Bakanlığı Öğretmenevi, Öğretmenevi ve Akşam Sanat Okulu Uygulama Yönergesi"nde, "Öğretmenevi, öğretmenevi ve akşam sanat okulu: Aslî fonksiyonları eğitim çalışanlarının konaklama ihtiyacını karşılamak olan, ayrıca yeme-içme, spor, eğlence ve eğitim intiyaçları için yardımcı ve tamamlayıcı birimleri de bünyelerinde bulunduran kurumları"; "Eğitim çalışanı: Bakanlık kadrolarında görev yapanlar ile özel öğretim kurumlarındaki eğitim personelini ve bunların emeklilerini"; "Kurum: Öğretmenevi ile öğretmenevi ve akşam sanat okulunu"; "Kurum personeli: Kurum intiyaçları doğrultusunda, ücreti kurum gelirlerinden karşılanmak üzere doğrudan kurum tarafından çalıştırılan işçi veya hizmet alımı yolu ile çalıştırılan personeli" şeklinde belirtilmiştir. Bu bulgunun nedeni Milli Eğitim Bakanlığı Teftiş Kurulu Başkanlığı tarafından yayınlanan 16 denetim rehberinin ilk bölümlerinin aynı olması olabilir ancak söz konusu rehberin öğretmenevleri ve akşam sanat okullarının denetiminde kullanıldığı göz önüne alındığında, belirtilen tanımların da rehberde yer alması gerekliliğinden söz edilebilir. 
"Yasal dayanağın hatalı ifade edilmesi" $(f=2)$ rehberin yasal belgelerle tutarsızlı̆̆ kategorisinde yer alan ve az ifad edilen diğer bir koddur. Rehberde atıf yapılan yasal belgenin ismi ya da madde numarası doğru ifade edilmediğinde bu kod tercih edilmiştir. Örnek vermek gerekirse; rehberde "Milli Eğitim Bakanlığı Kurum Tanıtma Yönetmeliğinde belirtilen işlemlerin yerine getirilme durumu" şeklinde ifade edilen yönetmeliğin ismi, "Millî Eğitim Bakanlığı Kurum Tanıtım Yönetmeliği"dir. Yine rehberde "Elektrik İç Tesisat Yönetmeliği" şeklinde belirtilen yönetmeliğin ismi ise "Elektrik iç Tesisleri Yönetmeliği"dir.

"Yasal dayanağa göre fazla ifade edilme" ( $f=1)$ kodu ise rehberin yalnızca bir yerinde görülmektedir ve rehberde yer alan ifadenin atıf yapılan yasal dayanağa göre fazla veya detaylı ifade edilmesi durumunda tercih edilmiştir. Rehberde "Rehberlik ve Denetim İlkeleri" başığında yer alan ilkeler, 20.08.2017 tarihli ve 30160 sayılı Teftiş Kurulu Yönetmeliği'nin 47. Maddesinde belirtilen ilkelerle çoğunlukla örtüşmekle birlikte, rehberde birkaç ilkenin daha fazla olduğu görülmektedir. Bu bulgu denetim rehberini hazırlayanların, söz konusu yönetmelikte belirtilen ilkelere göre farklı noktalara vurgu yapmak istemesi şeklinde yorumlanabilir. Aşağıda rehberde belirtilen 13 ilkeden yalnızca yönetmelikte belirtilen ilkelere göre fazla olanlar alıntı olarak verilmiştir:

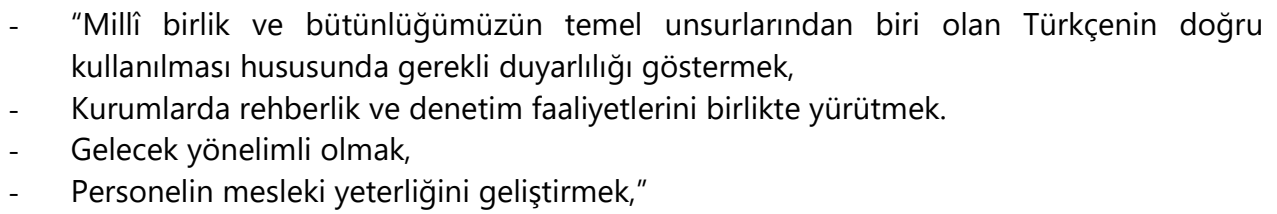

\section{2. Öğretmenevleri, Öğretmenevi ve Akşam Sanat Okulları Denetim Rehberinin Alanyazına Uygunluğu}

Denetim rehberinin alanyazına uygunluğunun değerlendirilmesi amacıyla, rehberdeki ifadeler incelenmiş; alanyazınla kıyaslandığında alanyazına uygunluğu, içerik eksikliği, atıfsızlığı ve aykırılığı gibi sorulara yanıt aranmıştır. Tablo 3 'de denetim rehberinin alanyazına uygunluğunun değerlendirilmesi sonucunda ulaşılan tema, kategori ve kodlar belirtilmiştir. Denetim rehberinin alanyazına uygunluğu incelenirken, yalnızca kategori ve kodlar belirlenmiş, bu kategori ve kodlarda sayısallaştırma yoluna gidilmemiştir.

Tablo 3. Öğretmenevleri, Ögrretmenevi ve Akşam Sanat Okulları Denetim Rehberinin Yasal Belgelere Uygunluğu

\begin{tabular}{|c|c|c|}
\hline Tema & Kategoriler & Kodlar \\
\hline \multirow{4}{*}{ 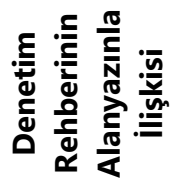 } & Denetim Rehberinin Alanyazınla Tutarlıığı & Uygunluk \\
\hline & \multirow{3}{*}{ Denetim Rehberinin Alanyazınla Tutarsızlığı } & İçerik eksikliği \\
\hline & & Atıfsızlık \\
\hline & & Aykırılık \\
\hline
\end{tabular}

Tablo 3'de belirtildiği üzere, denetim rehberinin alanyazınla ilişkisi "Denetim Rehberinin Alanyazınla Tutarlıı̆ı" ve "Denetim Rehberinin Alanyazınla Tutarsızlı̆ı" kategorilerinde ve alanyazınla tutarsızlığı ise "içerik eksikliği", "Atıfsızlık" ve "Aykırılık" kodlarıyla ele alınmıştır.

Denetim rehberi incelendiğinde, rehberin alanyazınla genel olarak tutarlı olduğu söylenebilir. Bu bulgu, rehberin hazırlanmasında denetim alanyazınına hâkim kişilerden destek alınması ile ilişkili olabilir. Denetim alanyazını için sevindirici bir bulgu olarak yorumlanabilecek bu sonuç, denetimde teori ve uygulama açısından bir tutarlılık olduğunu da gösterebilir. Her ne kadar rehber alanyazınla genel olarak tutarlı görünse de; alanyazına göre içerik olarak eksik olan, alanyazına aykırı yani alanyazınla çelişen ve düzeltilmesi gereken ifadelerin bulunması ve en önemlisi alanyazınla ister tutarlı ister tutarsız olsun rehberin konusu ile ilgili yapılmış bilimsel 
çalışmalara gönderme yapılmaması eleştirilebilecek bir durumdur. Oysa denetlenenlere rehberlik etmek; sunulan hizmetlerin kontrol ve denetimini yapmak, süreç ve sonuçlarını analiz etmek ve Maarif Müfettişleri Başkanlıkları arasında uygulama birliği ve standartlaşmayı sağlamak amacıyla hazırlanan rehberin tamamen bilimsel bilgiler ışığında ve denetim alanyazını çerçevesinde hazırlanması ve yararlanılan kaynaklara rehberde atıf yapılması beklenirdi.

Denetim rehberinin alanyazınla tutarlılığı, "Uygunluk" koduyla ele alınmıştır. Rehberde yer alan ifadeler, alanyazındaki çalışmalarla tutarlıysa bu kod tercih edilmiştir. Bu bağlamda rehberin "Denetim Illkeleri" bölümü örnek olarak gösterilebilir. Mesela "Bireysel ve kurumsal farkllıklar ile çevresel faktörleri dikkate almak", "Açıklk, şeffaflık, eşitlik, demokratiklik, bağımsızlık, bütünlük, güvenilirlik ve tarafsızlı̆ı esas almak,", "işbirliği ve katılımı öngörmek" ve "Objektif olmak" ilkeleri alanyazında da dile getirilen ilkelerdir. Örneğin Gökçe (1994), "Denetimle ilgili veriler ve denetim sonuçlarının denetlenenlere açık olarak bildirilmesini; denetimin, demokratik katılımı, katılanların işbirliğini ve eşgüdümünü esas almasını; öğrenci, okul ve çevre koşullarının dikkate alınmasını; denetimin, nesnel bulgulara ve bilimsel esaslara dayalı olmasını ve denetimde bireysel farklılıkların göz önünde bulundurulmasını denetimin ilkeleri arasında belirtir. Benzer şekilde Erdoğan (2002)'a göre de tamamlıık, gerçeklik, doğruluk, açıklık ve tarafsızlık denetimin ilkeleri arasında yer alır.

Denetim rehberinin alanyazınla tutarsızlığı kategorisi çerçevesinde ele alınan ilk kod "iç̧erik Eksikliği"dir. İçerik eksikliği kodu, alanyazında olup da denetim rehberinde olmayan ya da rehberde olan ancak alanyazına göre ilave bilgi gerektiren durumlar tespit edildiğinde tercih edilmiştir. Örneğin rehberde "Yönetim Faaliyetleri" başlığında yer alan "Personel isşleri" bölümünde, personel istihdamı, personel izin-rapor ile giriş-çıkış saatlerinin düzenlenmesi, kılıkkıyafet, hijyen eğitimi, nöbet hizmetleri, disiplin, ceza ve ödül durumu gibi konulara yer verilirken; denetimin personel geliştirme işlevi üzerinde durulmamıştır. Oysa çağdaş denetim anlayışının denetimi, eğitim işgörenlerinin mesleksel gelişmelerini teşvik eden sosyal bir süreç olarak gördüğünü söylemek mümkündür (Başaran, 1982: 104). Yine alanyazında kurumun amaçlarına ulaşabilmesi için personele yapılan mesleki rehberlik olarak da tanımlanabilecek denetim, personelin görevlerini yapma biçimini değerlendirmek, hata ve eksikliklerini ortaya koymak ve bunları düzeltebilmeleri için yardımda bulunma süreci olarak tanımlanmaktadır (Taymaz, 2002: 31). Rehberde alanyazına göre içerik eksikliğinin bulunmasının sebebi, rehberin hazırlanırken alanyazından yeterince yararlanılmaması olabilir.

Rehberin alanyazınla tutarsızlığı çerçevesinde ele alınan diğer bir kod da "Atıfsızlık" dır. Atıfsızık, rehberin alanyazınla ilişkisi ister tutarlı ister tutarsız olsun rehberin konusu ile ilgili yapılmış bilimsel çalışmalara gönderme yapılmaması durumunu ifade etmektedir. Örneğin, rehberde her bölümün sonunda yer alan "Çözüm Önerileri" başlığında "Bakanlığa, iVilçe milli eğitim müdürlügüne, kuruma yönelik olarak; kurumun gelişimine katkı sağlayacak, değer katacak, geleceğe ilişkin bir vizyon oluşturacak, aynı zamanda gerçekçi ve uygulanabilir önerilere yer verilmelidir" ifadesi yer almaktadır. Burada kurum denetimine ilişkin alanyazın temelli bilimsel önerilere atıf yapılarak ve araştırmacıların sunduğu çözüm önerilerine yer verilerek denetim sürecinin bilimselliği sağlanabilir. Aslında yalnızca yukarıda verilen örnekte değil, rehberin hiçbir yerinde alanyazındaki herhangi bir araştırmaya, kitaba, çalışmaya atıf yoktur. Bu bulgunun elde edilmesinin sebebi, rehberin sadece mevzuat odaklı hazırlanarak bilimsel bilginin göz ardı edilmesi şeklinde açıklanabilir. Diğer yandan rehberin var olan haliyle alanyazınla tutarlı çıkan yanları itibariyle o kısımların gönderme yaptığı mevzuatın şekillenişi ya da oluşturulması esnasında bilimsel bilgiden hareket edilmiş olabileceğine ilişkin bir ipucu da verebilir. Zaten, eğitbilimciler eğitim pratiğinin teorilerini hazırladıklarında, bu teoriler üretildiği toplumun ve belki de uluslararası toplumun gerçekten (hukuksal anlamda) yasal belgelerine yansıdığında ancak (o ülkede ya da dünyada) eğitimin bilimliliğinden söz edilebilir (Toprakçı, 2008; Toprakçı, Dağdeviren, Oflaz ve Türe 2010). Eğitim denetimi akademisyenlerinin ürettiği bilginin işlerliği açısından uygulamadakilerin onların çalışmalarından atıf yaparak yararlanmaları hem 
uygulamaya nitelik kazandırmak hem de akademisyeni takdir etmek bağlamlı katkı sağlayıcı olabilir.

Rehberin alanyazınla tutarsızığını vurgulayan son kod "Aykırılık" kodudur. Aykırılık kodu, denetim rehberinde alanyazınla çelişen bir ifade olduğunda tercih edilmiştir. Bu bağlamda denetim rehberinin "Ön Çalışma (Bilgi Toplama/Ön Araştırma, Potansiyel sorunlu alanların belirlenmesi-Risk değerlendirmesi, Denetim araçlarının belirlenmesi, denetim öncesi hazırlık toplantısı) ve Alanda Denetim Uygulaması (Rehberlik ve Denetim Uygulama Süresi, Bulguların Elde Edilmesi ve Önerilerin Geliştirilmesi, Bulguların Denetlenen Kurumla Paylaşılması, Değerlendirme Toplantısı)" örnek olarak gösterilebilir. Bu bölümde aslında denetimin öğeleri anlatılmaktadır. Erdoğan (2002: 74) denetimin öğelerini kontrol, değerlendirme ve düzeltme olarak açıklamıştır. Gökçe'ye (1994) göre ise denetimin öğeleri durum saptama, değerlendirme, düzeltme ve geliştirmedir. Eğitimde denetimin durum saptama öğesinde, önceden belirlenmiş amaçlarının gerçekleşme durumunun belirlenmesi amaçlanırken; değerlendirme aşamasında denetim sonuçlarının kriterlerle karşılaştırılması ve sonuç hakkında bir yargıda bulunulması amaçlanır. Düzeltme ve geliştirme ise, sapma göstermiş amaçların düzeltilmesi ve etkililiği sağlamak amacıyla yeni amaçların geliştirilmesi eylemlerini içerir. Rehberde alanyazına aykırı ifadelerin bulunmasının sebebi, rehberi hazırlayan kişilerin yalnızca mevzuat odaklı düşündüğü ve denetim sürecinin, bilimsel bilgiler ışığında gerçekleştirilmesinden ziyade mevzuata ve önceden belirlenen amaçlara uygunluğunun denetlenmesi şeklinde yorumlanması olabilir.

\section{SONUÇ VE ÖNERILER}

Araştırmanın sonuç bölümünde her bir tema ve kategori için sonuçlara ve önerilere yer verilmiştir.

1. Denetim rehberinin, yasal belgelerle genel olarak uyumlu olduğu söylenebilir.

- Eğitim kurumlarının denetimi, her şeyden önce bu kurumların yasal mevzuata uygunluğu temelinde yapılmalıdır. Bu nedenle denetim rehberi de yasal metinlerle uyumlu olmalıdır. Bu noktada rehberi hazırlayanlara, rehberin yasal metinlerle tutarlılığının sürdürülmesi, tutarsız olduğu noktaların ise tespit edilerek tutarlı hale getirilmesi önerilebilir.

- Bu çalışmanın bir amacı, öğretmenevi ve akşam sanat okullarının denetiminin sağlıklı bir şekilde sürdürülebilmesi adına denetim rehberinin yasal metinlerle tutarlılığının incelenmesidir. Bu amaç etrafında denetim rehberinin yasal metinlerle genel olarak tutarlı olduğu da söylenebilir ancak denetimler sonucunda maarif müfettişleri tarafından hazırlanan raporların yasal belgelerle ne kadar tutarlı olduğu, yalnızca denetim öncesi değil denetimler sırasında da yasal belgelerin ne kadar dikkate alındığının anlaşılması açısından önemlidir. Bu anlamda araştırmacılara denetim sonrasında hazırlanan raporların da yasal belgelerle tutatrlıı̆ıını araştırılması önerilebilir.

2. Denetim rehberi her ne kadar yasal belgelerle genel olarak tutarlı görünse de, rehberde atıf yapılan birçok yasal belgenin güncel olmadığı, ilgili yasal dayanaklara eksik gönderme yapıldığı, yasal belgeye göre eksik, hatalı ya da fazla ifade edildiği, atıf yapılan yasal belgeye internet ortamında ulaşılamadığı, ilgili konuya ilişkin yasal belgeye açıkca gönderme yapılmadığı ve rehberde yer alan içeriğe ilişkin hiçbir yasal belgenin olmadığı da araştırmanın diğer sonuçlarıdır.

- Araştırmanın sonuçlarına göre denetim rehberinin yasal belgelerle tutarsızlığı azımsanamayacak boyuttadır. Her ne kadar rehberde denetimler sırasında yürürlükteki hukuki düzenlemelerin dikkate alınması, denetim rehberinde yer almayan hususların ise ilgili mevzuat hükümlerine göre yapılması gerektiği söylense de; bu bulgunun denetim 
sürecinin sağlıklı işleyebilmesi adına sorun teşkil edeceği düşünülmektedir. Bu nedenle rehberi hazırlayanlara, denetim rehberinin ilgili yasal belgeler dikkate alınarak revize edilmesi ve değişen, yürürlükten kaldırılan ya da yeni çıkarılan yasal belgeler çerçevesinde rehberin düzenli olarak güncellenmesi önerilebilir.

- Araştırmanın "denetim rehberinin yasal belgelerle tutarsızlığı" kategorisinde ulaşılan sonuçları kapsamında, araştırmacılara rehberin yasal belgelerle uyumsuzluğundan kaynaklanan, denetimler sırasında yaşanan aksaklıklar, ortaya çıkan zorluklar ve denetimin sağlıklı bir şekilde işlemesini engelleyen durumlarla ilgili maarif müfettişlerinin görüşlerinin alındığı çalışmaların yapılması önerilebilir.

3. Denetim rehberi, denetim alanyazını ile genel olarak tutarlı görünmektedir.

- Eğitim kurumlarının denetimi, öncelikli olarak bu kurumların yasal mevzuata uygunluğu temelinde gerçekleştirilse de, rehberin denetim alanyazını çerçevesinde hazırlanmış olması gerekir. Çünkü diğer tüm eğitim kurumları gibi bu kurumların da denetiminin bilimsel bilgiler ışığında gerçekleşmesi, özellikle denetimin düzeltme ve geliştirme işlevleri açısından önemlidir. Zira eğitimde gelişme ve ilerlemenin sağlanması ancak bilimin temele alındığı bir denetim anlayışı ile mümkündür. Bu nedenle karar alıcı konumundakilere, denetim rehberinin hazırlanmasında denetim alanyazınının temele alınmasının sürdürülmesi ve bilimsel bilgiler ışığında güçlendirilmesi önerilebilir.

- Bu çalışmada denetim rehberlerinin bilimselliği doküman incelemesi yöntemiyle denetim alanyazını çerçevesinde araştırılmıştır. Bu noktada araştırmacılara öğretmenevleri ve akşam sanat okullarının denetimini gerçekleştiren maarif müfettişlerinin denetim rehberinin bilimselliği ile ilgili görüşleri alınarak bir çalışma gerçekleştirmeleri önerilebilir.

4. Denetim rehberi, denetim alanyazını ile genel olarak uyumlu görünse de; denetim rehberinde alanyazına göre içerik olarak eksik olan ve alanyazına aykırı yani alanyazınla çelişen ve düzeltilmesi gereken birçok ifade bulunmaktadır. Ayrıca en önemlisi rehberde, alanyazınla ister tutarlı ister tutarsız olsun rehberin konusu ile ilgili yapılmış hiçbir bilimsel çalışmaya gönderme yapılmamıştır.

- Denetim rehberinin alanyazınla tutarsızığı çerçevesinde karar alıı konumundakilere, rehberin hazırlanması sürecinde akademisyenlerin de görüşlerinin alınması, bu anlamda rehberin bilimsel bilgiler temele alınarak ve alanyazına atıfta bulunarak güncellenmesi önerilebilir.

- Tüm eğitim kurumları gibi öğretmenevleri ve akşam sanat okullarının da işleyişini sağlıklı bir şekilde yürütebilmesi açısından denetimler süresince müfettişlerin de bilimselliği temele alarak personele rehberlik etmesi, denetim rehberinin bilimsel bilgiler ışığında hazırlanması kadar önemlidir. Bu nedenle maarif müfettişlerinin denetim alanyazınına hâkim olmaları açısından lisansüstü eğitim almalarının teşvik edilmesi önerilebilir.

\section{KAYNAKLAR}

Arslan, A. (2002). Kamu harcamalarında verimlilik, etkinlik ve denetim. Maliye Dergisi. 140.

Aslanargun, E. ve Göksoy, S. (2013). Öğretmen denetimini kim yapmalıdır? Uşak Üniversitesi Sosyal Bilimler Dergisi. Özel Sayı. 20. 98-121.

Aslanargun, E. ve Tarku, E. (2014). Öğretmenlerin mesleki denetim ve rehberlik konusunda müfettişlerden beklentileri. Kuram ve Uygulamada Eğitim Yönetimi. 20 (3). 281-306.

Aydın, i. (2008). Öğretimde denetim. Ankara: Pegem Akademi Yayıncılık.

Aydın, M. (2014). Çağdaş eğitim denetimi. Ankara: Gazi Kitabevi. 
Balcı, A., Demirkasımoğlu, N., Erdoğan, Ç. ve Akın, U. (2011). Turkish teachers' and supervisors' metaphorical perceptions about supervisors. International Research Journals. 2(10). 1602-1610.

Başaran, İ.E. (1982). Örgütsel Davranış. Ankara: Ankara Üniversitesi Eğitim Fakültesi Yayınları.

Başaran, I.E. (2008). Türk eğitim sistemi ve okul yönetimi. Ankara: Ekinoks Yayınevi.

Bogdan, R.C. ve Biklen, S. K. (1998). Qualitative research for education: An introduction to theory and methods. Boston: Allyn \& Bacon.

Bowen, G.A. (2009). Document analysis as a qualitative research method. Qualitative Research Journal. 9 (2). 27-40. https://doi.org/10.3316/QRJ0902027. Erişim Tarihi: 12.08. 2020

Dündar, A. A. (2005). ilköğretim okullarında yapılan teftişin okul başarısı ve gelişimi üzerine etkisi. Yüksek Lisans Tezi. Gazi Üniversitesi Eğitim Bilimleri Enstitüsü. Ankara.

Erdoğan, M. (2002). Muhasebe, denetim ve bağımsız denetimin gerekliliği. Doğuş Üniversitesi Dergisi, (5): 51-63.

Gökçe, F. (1994). Eğitimde denetimin amaç ve ilkeleri. Hacettepe Üniversitesi Eğitim Fakültesi Dergisi. (10) 73-78.

MEB (2013). Millî Eğitim Bakanlı̆̆ı Öğretmenevi, Öğretmenevi ve Akşam Sanat Okulu Uygulama Yönergesi http://dhgm.meb.gov.tr/dosyalar/Yonerge/ogretmenevleri_uygulama_yonergesi.pdf Erişim Tarihi: 08.07.2020

MEB (2016). Öğretmenevleri, öğretmenevi ve akşam sanat okulları rehberlik ve denetim rehberi. https://tkb.meb.gov.tr/www/yayinlarimiz/icerik/13. Erişim Tarihi: 08.07.2020

Memduhoğlu, H. B. (2012). Öğretmen, yönetici, denetmen ve öğretim üyelerinin görüşlerine göre Türkiye'de eğitim denetimi sorunsalı. Kuram ve Uygulamada Eğitim Bilimleri. 12(1), 135-156.

Merriam, S. B. (2013). Nitel Araştırma Desen ve Uygulama için bir rehber. Çev. Edt. Selahattin Turan. Ankara: Nobel Yayın.

Öz, M. F. (2003). Türkiye Cumhuriyeti milli eğitim sisteminde teftiş. Eskişehir: Osmangazi Üniversitesi Yayınları.

Patton, M. Q. (2014). Nitel araştırma ve değerlendirme yöntemleri. (M. Bütün, S. B. Demir, Çev.). Ankara: Pegem Akademi Yayıncılık.

Sağlam, H. (2014). Öğretmenevleri niçin gerekli?. Ayrıntı Dergisi. 2 (12).

Sergiovanni, T. J. ve Starratt, R. J. (2002). Supervision: A redefinition (7th edition). Boston: McGraw-Hill, Inc.

Taymaz, H. (2002). Eğitim sisteminde denetim kavramlar, ilkeler, yöntemler. Ankara: Pegem Akademi Yayıncılık.

Teftiş Kurulu Başkanlığı (2019). Bakanlık Maarif Müfettişleri Görev Standartları. http://tkb.meb.gov.tr/meb_iys_dosyalar/2019_06/19145017_BakanlYk_Maarif_MuYfettisYleri_GoYrev _StandartlarY.pdf. Erişim Tarihi: 10.07.2020

Topçu, ì. (2010). Devlet ve özel ilköğretim okullarında yöneticilerin öğretimin denetimi görevlerini yerine getirme biçimleri. C.Ü. Sosyal Bilimler Dergisi. 34 (2). 31-39.

Toprakçı, E. (2008). Sınıfa dayalı yönetim. Ankara: Pegem Akademi Yayıncılık.

Toprakçı, E., Dağdeviren, İ., Oflaz, G. ve Türe, E. (2010). Eğitim fakültesi öğretim elemanlarının bilim anlayışları temelinde eğitimin bilimliliği. Bilim ve Ütopya Dergisi. 190 (10). 4556 https://www.erdaltoprakci.com.tr/wp-content/uploads/2020/05/bilimanlay\%C4\%B1\%C5\%9Flar\%C4\%B1-temelinde-e\%C4\%9Fitimin-bilimlili\%C4\%9Fi.pdf Erişim Tarihi: 12. 07.2020

Vatanartıran, S. ve Güvenç, M. L. (2014). İstanbul ilindeki öğretmenlerin, öğretmenevleri üzerine görüşleri. Elektronik Sosyal Bilimler Bilimler Bilimler Dergisi. 13 (51). 168-181.

Yıldırım, H. ve Şimşek, A. (2008). Sosyal bilimlerde nitel araştırma yöntemleri (7. Baskı). Ankara: Seçkin Yayıncılık. 


\title{
The Examination of Supervisory Guideline of Teachers' Houses and Teachers' Houses and Evening Arts Schools on the Basis of Legal Documents and Literature
}

\author{
Asts. Prof. Hilal Kahraman \\ Sivas Cumhuriyet University \\ hyucel@cumhuriyet.edu.tr
}

\begin{abstract}
One of the processes performed in evaluating the effectiveness of educational activities is supervision. The main purpose of the supervision is to determine the degree to which educational goals are achieved and to take measures to achieve better results. The aim of this study is to examine the supervisory guideline of teachers' houses and teachers' houses and evening arts schools on the basis of legal documents and educational supervision literature. The document analysis method, which is one of the qualitative research methods, was used in the study, and the data were subjected to content analysis. According to the results of the study, it can be argued that the guideline is generally consistent with legal documents, but some articles are not up to date according to legal documents and that there is uncertainty of legal basis and inconsistency with legal documents in points such as missing reference to the relevant legal bases. In addition, while it can be argued that the guideline is generally consistent with the literature, the inconsistency with the literature can be associated with the lack of content and reference and also with contradicting codes.
\end{abstract}

Keywords: Educational Supervision, Supervisory guideline, Teachers' House, Evening Art Schools.

\section{E-International Journal of Educational Research, Vol: 11, No: 3, 2020, pp.123-138}

DOI: 10.19160/ijer.836759

\section{Suggested Citation:}

Kahraman, H. (2020). The Examination of the Supervisory Guideline of Teachers' Houses and Teachers' Houses and Evening Arts Schools on the Basis of Legal Documents and Literature, E-International Journal of Educational Research, Vol: 11, No: 3, 2020, pp. 123-138, DOI: 10.19160/ijer.836759 


\section{EXTENDED ABSTRACT}

Problem: Progress and improvement in education is through supervision. In educational supervision, in which it is aimed to have information about the degree of achievement of the objectives, the organizational functioning as a whole is constantly monitored in a planned and programmed manner, deficiencies are determined and corrected; attempts are made to prevent the renewal of errors and to achieve a healthier operation. Supervision processes in the units affiliated to the Ministry of National Education are carried out by the Ministry of Education Supervisors. The responsibilities of Education Supervisors are guidance, auditing, examination, investigation, preliminary examination, research and monitoring-evaluation. One of the guidelines prepared for determining the principles that assists the supervision processes and guides the supervision processes is the "Supervisory Guideline for Teachers' Houses and Teachers' Houses and Evening Art Schools. The aim of this study is to examine the compliance of the teachers' houses and teachers' houses and evening arts schools' supervisory guideline with the legal legislation and literature.

Method: In this study, document analysis method was used within the scope of qualitative studies aiming to study a situation or event in depth and in detail.

The main document of this study is the "Teachers' houses and teachers' houses and evening arts schools' supervisory guideline", which includes the principles to be applied by education supervisors in the supervision process by the Ministry of National Education Supervision Board. Content analysis was used in the analysis of the study data. First, the consistency of the guideline with the legal documents was examined; the codes, categories and themes were determined and their equivalents in the guideline were expressed by digitizing. Later, within the framework of the coherence of the guideline with the literature, the guideline was repeatedly read by the researcher on the basis of the researcher's mental framework of the literature, and during these readings, the codes, categories and themes were determined. "Multiple analyst triangulation" and "expert examination" methods were used to ensure the validity and reliability of the study. For the multianalyst triangulation, researchers who examined the supervision guidelines of the MNE Supervision Board for different institutions came together regularly every week on the specified day and time on the internet via live meeting tools and they created the codes, categories and themes by analyzing the content of the guidelines and focused on the similar and different aspects. The points of disagreement were evaluated, and the meetings continued until a consensus was reached. For the expert review, an academician who is competent in the field of auditing and who has publications, and an education supervisor participated in this meeting and provided feedback during the meeting. After the final meeting, the study was sent to expert academicians in the field of study and their views were also included in the study.

Findings: The findings of the study are presented under the titles "Compliance of Supervisory Guideline for Teachers' Houses and Teachers' Houses and Evening Art Schools with Legal Documents" and "Compliance of Supervisory Guideline for Teachers' Houses and Teachers' Houses and Evening Art Schools with the Literature". In order to evaluate the conformity of the supervision guide with the legal documents, the legal documents which have been referred to in the guideline and the ones which are required to be referred were examined.

As a result of the examinations, the category of "Consistency of Supervisory Guide with Legal Documents" was examined with the code "Compliance with Legal Basis". The category of "Inconsistency of Supervisory Guide with Legal Documents" was examined with "Not being up-todate according to legal basis", "Uncertainty of legal basis", "Missing reference to relevant legal bases", "Legal gap", "Inability to reach legal basis on internet", "Incomplete expression according to legal basis", "Being expressed", "Misrepresenting the legal basis" and "Over-expressing according to the legal basis" codes.

It can be said that the guideline is generally consistent with legal documents (f: 108). However, it can be mentioned that many items in the isupervisory guideline (f: 97 ) created to 
determine the principles to be applied in the supervision of teachers' houses and evening arts schools are inconsistent with legal documents. When the findings are evaluated in general; it is an expected finding that the supervisory guideline will be consistent with the legal documents that reference the supervisory. However, codes that emphasize the inconsistency of the guideline with legal documents, such as incorrect expression of the legal basis referred to in the guideline, ambiguity, outdatedness, incompleteness, inaccuracy or over-expressiveness, are the findings encountered in the guideline and can be evaluated as negative.In order to evaluate the appropriateness of the supervisory guide to the literature, the statements in the guideline were examined and their compatibility with the literature was evaluated. "Consistency of the Supervisory Guide with the Literature" category was handled with the "Conformity" code and "Inconsistency of the Supervisory Guide with the Literature" category with "Lack of Content", "Non-Attribution" and "Inconsistency" codes.

When the supervisory guide is examined, it can be said that the guideline is generally consistent with the literature. The reason for this finding may be the support from people who have a good command of the supervision literature in the preparation of the guideline. This result, which can be interpreted as a positive finding for the supervision literature, may also show that there is a consistency in terms of theory and practice in supervision. Although the guideline seems to be generally consistent with the literature, it is a pity that there are expressions that are lacking in terms of content according to the literature, that are in contradiction with the literature and that need to be corrected, and most importantly, there are no references to scientific studies made on the subject of the guideline, whether it is consistent or inconsistent with the literature. However, to guide the inspected, it was expected that the guideline, which was prepared in order to control the services provided, to analyze the processes and results, and to ensure unity and standardization between the Presidencies of Education Supervisory, was prepared in the light of scientific information and within the framework of the audit literature, and to refer to the sources used in the guideline.

Recommendations: The supervisory guide is related to both legal documents and the literature. However, there are many expressions in the guideline that are inconsistent with both the legal documents and the literature. Although the situation with the supervisory guide is not very different, it exhibits more consistency with legal documents. The inconsistency of the supervisory guide with legal documents is most often seen in codes which are outdated according to the legal basis, ambiguity of the legal basis and missing reference to the relevant legal bases. Although the supervisory guide is generally consistent with the literature, it has been found that there are incomplete and contradictory statements in terms of content according to the literature and no reference is made to scientific studies anywhere in the guideline. 